\title{
Front Matter: Volume 8635
}

, "Front Matter: Volume 8635," Proc. SPIE 8635, Advances in Photonics of Quantum Computing, Memory, and Communication VI, 863501 (12 April 2013); doi: $10.1117 / 12.2022942$

SPIE. Event: SPIE OPTO, 2013, San Francisco, California, United States 


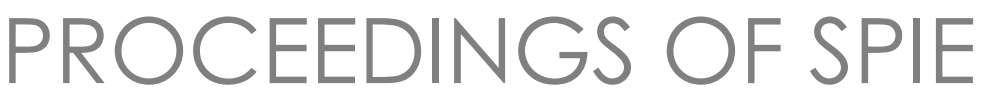

\section{Advances in Photonics of Quantum Computing, Memory, and Communication VI}

Zameer U. Hasan

Philip R. Hemmer

Hwang Lee

Charles M. Santori

Editors

4-7 February 2013

San Francisco, California, United States

Sponsored and Published by

SPIE 
The papers included in this volume were part of the technical conference cited on the cover and title page. Papers were selected and subject to review by the editors and conference program committee. Some conference presentations may not be available for publication. The papers published in these proceedings reflect the work and thoughts of the authors and are published herein as submitted. The publisher is not responsible for the validity of the information or for any outcomes resulting from reliance thereon.

Please use the following format to cite material from this book:

Author(s), "Title of Paper," in Advances in Photonics of Quantum Computing, Memory, and Communication VI, edited by Zameer U. Hasan, Philip R. Hemmer, Hwang Lee, Charles M. Santori, Proceedings of SPIE Vol. 8635 (SPIE, Bellingham, WA, 2013) Article CID Number.

ISSN: 0277-786X

ISBN: 9780819494047

Published by

SPIE

P.O. Box 10, Bellingham, Washington 98227-0010 USA

Telephone +1 3606763290 (Pacific Time) · Fax +1 3606471445

SPIE.org

Copyright @ 2013, Society of Photo-Optical Instrumentation Engineers.

Copying of material in this book for internal or personal use, or for the internal or personal use of specific clients, beyond the fair use provisions granted by the U.S. Copyright Law is authorized by SPIE subject to payment of copying fees. The Transactional Reporting Service base fee for this volume is $\$ 18.00$ per article (or portion thereof), which should be paid directly to the Copyright Clearance Center (CCC), 222 Rosewood Drive, Danvers, MA 01923. Payment may also be made electronically through CCC Online at copyright.com. Other copying for republication, resale, advertising or promotion, or any form of systematic or multiple reproduction of any material in this book is prohibited except with permission in writing from the publisher. The CCC fee code is 0277-786X/13/\$18.00.

Printed in the United States of America.

Publication of record for individual papers is online in the SPIE Digital Library.

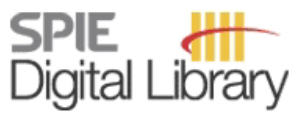

SPIEDigitalLibrary.org

Paper Numbering: Proceedings of SPIE follow an e-First publication model, with papers published first online and then in print and on CD-ROM. Papers are published as they are submitted and meet publication criteria. A unique, consistent, permanent citation identifier (CID) number is assigned to each article at the time of the first publication. Utilization of CIDs allows articles to be fully citable as soon as they are published online, and connects the same identifier to all online, print, and electronic versions of the publication. SPIE uses a six-digit CID article numbering system in which:

- The first four digits correspond to the SPIE volume number.

- The last two digits indicate publication order within the volume using a Base 36 numbering

system employing both numerals and letters. These two-number sets start with 00, 01, 02, 03, 04, $05,06,07,08,09,0 A, 0 B \ldots$. 0Z, followed by 10-1Z, 20-2Z, etc.

The CID Number appears on each page of the manuscript. The complete citation is used on the first page, and an abbreviated version on subsequent pages. Numbers in the index correspond to the last two digits of the six-digit CID Number. 


\title{
Contents
}

\author{
vii Conference Committee \\ xi Group IV photonics for the mid infrared (Plenary Paper) [8629-1] \\ R. Soref, The Univ. of Massachusetts at Boston (United States) \\ xxvii Light in a twist: optical angular momentum (Plenary Paper) [8637-2] \\ M. J. Padgett, Univ. of Glasgow (United Kingdom)
}

NONBLEACHING AND ULTRASMALL FLUORESCENT TAGS I

863503 Fluorescence lifetime imaging microscopy of nanodiamonds in vivo (Invited Paper) [8635-2]

Y. Kuo, Institute of Atomic and Molecular Sciences (Taiwan); T.-Y. Hsu, Y.-C. Wu, National Taiwan Univ. (Taiwan); J.-H. Hsu, National Sun Yat-Sen Univ. (Taiwan); H.-C. Chang, Institute of Atomic and Molecular Sciences (Taiwan)

863504 Upconverting fluorescent nanoparticles for biodetection and photoactivation (Invited Paper) [8635-3]

K. Huang, W. Li, M. K. G. Jayakumar, Y. Zhang, National Univ. of Singapore (Singapore)

NONBLEACHING AND ULTRASMALL FLUORESCENT TAGS II: JOINT SESSION WITH CONFERENCES 8596 AND 8635

863506 Nanodiamond imaging: molecular imaging with optically detected spin resonance of nitrogen-vacancy centers in nanodiamonds (Invited Paper) [8635-5]

A. Hegyi, E. Yablonovitch, Univ. of California, Berkeley (United States)

SPIN-BASED COMPUTING

8635 OA Optical generation of valley polarization in atomically thin semiconductors (Invited Paper) [8635-9]

X. XU, Univ. of Washington (United States); D. Xiao, Carnegie Mellon Univ. (United States);

W. Yao, The Univ. of Hong Kong (Hong Kong, China) 
8635 OB Ultrafast optical control of individual electron and hole spin qubits: entanglement between a single quantum dot electron spin and a downconverted 1560-nm single photon (Invited Paper) [8635-10]

K. De Greve, P. L. McMahon, L. Yu, J. S. Pelc, Stanford Univ. (United States);

C. M. Natarajan, Stanford Univ. (United States) and Heriot-Watt Univ. (United Kingdom);

D. Press, N. Y. Kim, Stanford Univ. (United States); E. Abe, Stanford Univ. (United States) and

National Institute of Informatics (Japan); D. Bisping, S. Maier, C. Schneider, M. Kamp, JuliusMaximilians-Univ. Würzburg (Germany); S. Höfling, Stanford Univ. (United States) and JuliusMaximilians-Univ. Würzburg (Germany); R. H. Hadfield, Heriot-Watt Univ. (United Kingdom); A. Forchel, Julius-Maximilians-Univ. Würzburg (Germany); M. M. Fejer, Stanford Univ. (United States); Y. Yamamoto, Stanford Univ. (United States) and National Institute of Informatics (Japan)

SPIN AND SINGLE-DEFECT PHOTONICS

8635 OE Microring resonator-based diamond optothermal switch: a building block for a quantum computing network [8635-13]

Z. Huang, Hewlett-Packard Labs. (United States); A. Faraon, Hewlett-Packard Labs. (United States) and California Institute of Technology (United States); C. Santori, V. Acosta,

R. G. Beausoleil, Hewlett-Packard Labs. (United States)

8635 OF NV center emission in a substrate free low index environment [8635-14]

F. A. Inam, Macquarie Univ. (Australia); M. D. W. Grogan, Univ. of Bath (United Kingdom) and Boston Univ. (United States); M. Rollings, Univ. of Bath (United Kingdom); T. Gaebel, S. Castelletto, J. M. Say, C. Bradac, T. A. Birks, W. J. Wadsworth, J. R. Rabeau, M. J. Steel, Macquarie Univ. (Australia)

\section{QUANTUM COMPUTING WITH PHOTONS}

8635 0J Opening of hidden capacity-domains of quantum channels [8635-18]

L. Gyongyosi, Budapest Univ. of Technology and Economics (Hungary) Information Systems Research Group (Hungary); S. Imre, Budapest Univ. of Technology and Economics (Hungary)

$8635 \mathrm{OL}$ High numerical aperture diffractive optical elements for neutral atom quantum computing [8635-20]

A. L. Young, S. A. Kemme, J. R. Wendt, T. R. Carter, S. Samora, Sandia National Labs. (United States)

\section{RARE-EARTH-DOPED QUANTUM MEMORIES I}

863500 Cavity enhanced rephased amplified spontaneous emission (Invited Paper) [8635-23] M. J. Sellars, K. Ferguson, S. E. Beavan, The Australian National Univ. (Australia) 
$86350 Q$ Optimal detuning for writing warm-atomic-vapor quantum memory in the presence of collisional fluorescence and four-wave mixing [8635-25]

I. Vurgaftman, M. Bashkansky, U.S. Naval Research Lab. (United States)

QUANTUM II: JOINT SESSION WITH CONFERENCES 8635 AND 8637

8635 0X Spectral properties of ultra-broadband entangled photons generated from chirped-MgSLT crystal towards monocycle entanglement generation [8635-32]

A. Tanaka, R. Okamoto, Hokkaido Univ. (Japan) and Osaka Univ. (Japan); H. H. Lim, National Institute for Materials Science (Japan); S. Subashchandran, M. Okano, Hokkaido Univ. (Japan) and Osaka Univ. (Japan); L. Zhang, L. Kang, J. Chen, P. Wu, Nanjing Univ. (China); T. Hirohata, Hamamatsu Photonics K.K. (Japan); S. Kurimura, National Institute for Materials Science (Japan); S. Takeuchi, Hokkaido Univ. (Japan) and Osaka Univ. (Japan)

\section{ULTRA-LOW-POWER SWITCHING IN QUANTUM AND NONLINEAR PHOTONICS II}

863516 Ultra-low-power all-optical switching with a single quantum dot in a photonic-crystal cavity (Invited Paper) [8635-41]

M. Bajcsy, Stanford Univ. (United States); A. Majumdar, Stanford Univ. (United States) and Univ. of California, Berkeley (United States); D. Englund, Stanford Univ. (United States) and Columbia Univ. (United States); J. Vučković, Stanford Univ. (United States)

863517 Coupling of quantum fluctuations in a two-component condensate (Invited Paper) [8635-42]

C. M. Trail, B. C. Sanders, Univ. of Calgary (Canada)

\section{NONCLASSICAL LIGHT SOURCES AND DETECTORS}

863518 Semiconductor sources of photon pairs (Invited Paper) [8635-43]

G. Weihs, Univ. Innsbruck (Austria) and Univ. of Waterloo (Canada); T. Günthner, B. Pressl, Univ. Innsbruck (Austria); R. Horn, Univ. of Waterloo (Canada); P. Abolghasem, B. J. Bijlani, D. Kang, A. S. Helmy, Univ. of Toronto (Canada)

863519 Semiconductor source of entangled photons at room temperature [8635-44]

A. Orieux, A. Eckstein, Lab. Matériaux et Phénomènes Quantiques, CNRS, Univ. Paris 7-Denis Diderot (France); A. Lemaître, Lab. de Photonique et de Nanostructures, CNRS (France); P. Filloux, T. Coudreau, P. Milman, Lab. Matériaux et Phénomènes Quantiques, CNRS, Univ. Paris 7-Denis Diderot (France); A. Keller, Institut des Sciences Moléculaires d'Orsay, CNRS, Univ. Paris-Sud 11 (France); I. Favero, G. Leo, S. Ducci, Lab. Matériaux et Phénomènes Quantiques, CNRS, Univ. Paris 7-Denis Diderot (France) 
86351 A A novel concept to generate single photons: incoherent conversion from the visible into the infrared spectrum [8635-45]

T. Schröder, Humboldt-Univ. zu Berlin (Germany) and Massachusetts Institute of Technology (United States); P. Jiang, Humboldt-Univ. zu Berlin (Germany) and China Univ. of Petroleum (China); F. Gädeke, M. Barth, Humboldt-Univ. zu Berlin (Germany); V. Lesnyak, N. Gaponik, A. Eychmüller, Technische Univ. Dresden (Germany); O. Benson, Humboldt-Univ. zu Berlin (Germany)

8635 1B Waveguide superconducting single-photon autocorrelators for quantum photonic applications [8635-46]

D. Sahin, Technische Univ. Eindhoven (Netherlands); A. Gaggero, Istituto di Fotonica e Nanotecnologie, CNR (Italy); G. Frucci, S. Jahanmirinejad, J. P. Sprengers, Technische Univ. Eindhoven (Netherlands); F. Mattioli, R. Leoni, Istituto di Fotonica e Nanotecnologie, CNR (Italy); J. Beetz, M. Lermer, M. Kamp, S. Höfling, Julius-Maximilians-Univ. Würzburg (Germany); A. Fiore, Technische Univ. Eindhoven (Netherlands)

Author Index 


\section{Conference Committee}

Symposium Chair

David L. Andrews, University of East Anglia Norwich (United Kingdom)

Symposium Cochairs

Alexei L. Glebov, OptiGrate Corporation (United States)

Klaus P. Streubel, OSRAM GmbH (Germany)

Program Track Chair

Zameer U. Hasan, Temple University (United States)

Conference Chairs

Zameer U. Hasan, Temple University (United States)

Philip R. Hemmer, Texas A\&M University (United States)

Hwang Lee, Lovisiana State University (United States)

Charles M. Santori, Hewlett-Packard Labs (United States)

Conference Program Committee

Dmitry Budker, University of California, Berkeley (United States)

Alan E. Craig, Montana State University (United States)

Jonathan Dowling, Lovisiana State University (United States)

Gurudev Dutt, University of Pittsburgh (United States)

James D. Franson, University of Maryland, Baltimore County

(United States)

Kai-Mei C. Fu, University of Washington (United States)

David Hughes, Air Force Research Laboratory (United States)

Fedor Jelezko, Universität Stuttgart (Germany)

Seth Lloyd, Massachusetts Institute of Technology (United States)

Hideo Mabuchi, Stanford University (United States)

Alan L. Migdall, National Institute of Standards and Technology

(United States)

Aleksander K. Rebane, Montana State University (United States)

Selim Shahriar, Northwestern University (United States)

Alan Eli Willner, The University of Southern California (United States)

Jörg Wrachtrup, Universität Stuttgart (Germany)

Horace P. Yuen, Northwestern University (United States)

M. Suhail Zubairy, Texas A\&M University (United States) 
OPTO Plenary Session

David L. Andrews, University of East Anglia Norwich (United Kingdom)

Alexei Glebov, OptiGrate Corporation (United States)

$1 \quad$ Nonbleaching and Ultrasmall Fluorescent Tags I

Philip R. Hemmer, Texas A\&M University (United States)

2 Nonbleaching and Ultrasmall Fluorescent Tags II: Joint Session with Conferences 8596 and 8635

Ramesh Raghavachari, U.S. Food and Drug Administration (United States)

Philip R. Hemmer, Texas A\&M University (United States)

3 Spin-based Computing

Charles M. Santori, Hewlett-Packard Labs (United States)

$4 \quad$ Spin and Single-Defect Photonics

Kai-Mei C. Fu, University of Washington (United States)

5 Quantum Computing with Photons

Alexander V. Sergienko, Boston University (United States)

6 Rare-Earth-Doped Quantum Memories I

Zameer U. Hasan, Temple University (United States)

Philip R. Hemmer, Texas A\&M University (United States)

7 Quantum Metrology

Olivier Pfister, University of Virginia (United States)

8 Quantum I: Joint Session with Conferences 8635 and 8637

David L. Andrews, University of East Anglia Norwich (United Kingdom)

9 Quantum II: Joint Session with Conferences 8635 and 8637

John C. Howell, University of Rochester (United States)

10 Rare-Earth-Doped Quantum Memories II

Philip R. Hemmer, Texas A\&M University (United States)

Zameer U. Hasan, Temple University (United States)

11 Ultra-Low-Power Switching in Quantum and Nonlinear Photonics I

Charles M. Santori, Hewlett-Packard Labs (United States) 
12 Ultra-Low-Power Switching in Quantum and Nonlinear Photonics II Hideo Mabuchi, Stanford University (United States)

13 Nonclassical Light Sources and Detectors

Kai-Mei C. Fu, University of Washington (United States)

Proc. of SPIE Vol. $8635863501-9$

Downloaded From: https://www.spiedigitallibrary.org/conference-proceedings-of-spie on 26 Apr 2023 Terms of Use: https://www.spiedigitallibrary.org/terms-of-use 
Proc. of SPIE Vol. $8635863501-10$

Downloaded From: https://www.spiedigitallibrary.org/conference-proceedings-of-spie on 26 Apr 2023 Terms of Use: https://www.spiedigitallibrary.org/terms-of-use 